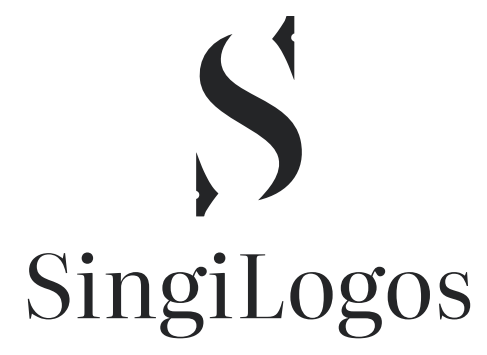

SINGILOGOS 2021, 1(1): $252-268$

ISSN: 2812-7005

UDK: $37.091 .3:: 811.111^{\prime} 36(497.6)$

"2020/2021"

37.091.3::811.111-057.874(497.6)

"2020/2021"

DOI: 10.18485/us_singilogos.2021.1.1.20

Original paper/Originalni naučni rad

(studentski rad)

\title{
ЗНАЧАЈ КОНТЕКСТА ЗА РАЗВИЈАЊЕ ГРАМАТИЧКЕ КОМПЕТЕНЦИЈЕ УЧЕНИКА СРЕДЬОШКОЛСКОГ УЗРАСТА
}

\author{
Марко Кукић* \\ Универзитет Сингидунум, \\ Департман за енглески језик
}

\section{Апстракт:}

Полазећи од тога да живимо у савременом свијету у коме сваки дан свједочимо напретку и развијању технологије, модерно друштво је допринијело да комплексне ствари постану разријешен клупко. Апропо тога, усвајање граматике енглеског језика на средњошколском нивоу, иако је изузетно комплексно, уз помоћ достигнућа олакшаће наставни трансфер знања и само усвајање граматике. Самим тим, данашњим професорима омогућен је, путем интернета, приступ оргиналним, језичким материјалима који могу служити ученицима да усвоје језик на начин на који га и сами говорници користе. Предмет овог рада представља процес учења и усвајања граматике енглеског језика коју сусрећемо у оквирима курикулума завршних година средњих школа. Рад је настао са циљем да анализира мјесто граматике у процесу наставе енглеског језика, начине и методе, као и типове задатака помоћу којих ученици усвајају граматичке цјелине. Посебна пажња се ставља на контекст, његову важност у процесу изучавања граматике на вишим нивоима и имплементацији задатака који садрже контекст. На корпусу сачињеног од језичке вјежбе и испитаних ставова ученика извршена је анализа задатака која има обавезу да укаже на значај контекста и мишљења ученика о истом.

\section{Article info:}

Received: June 20, 2021

Correction: July 19, 2021

Accepted: July 25, 2021

\section{УВОД}

Како су вијекови пролазили, свијет је напредовао и мијењао се; тако је долазило до еволвирања у усвајању енглеског језика и метода изучавања граматике. Иако је методика учења прошла дуг раскорак од екстремног граматичког дрила до потпуног

** Овај рад је настао као резултат истраживања спроведеног за потребе студентске конференције на којој је исто представљено.

\section{Кључне речи:}

енглески језик, граматика, методи, контекст, ставови, типови задатака. 
негирања - граматика, као саставни дио сваког језика, је остала неизоставни сегмент усвајања неког језика. Да бисмо показали зашто је граматика неизоставни сегмент, кренућемо од тога шта је граматика. У разним граматичким књигама, домаћих и страних аутора, наићемо на разне дефиниције граматике, стога је немогуће дати једну тачну коју ћемо користити али оно око чега се већина сложила јесте да је термин граматика синоним за скуп правила која говорник треба да испоштује при писменом или усменом изражавању како би са употребом шароликог вокабулара добио за резултат јасну, смислену реченицу. У својој докторској дисертацији Стокићка објашњава да је граматика покретач језика и да она генерише значење кроз односе између лексичких јединица. ${ }^{1}$ Самим тим, што је граматика покретач језика, њено изучавање преставља неопходност. У настави страног језика значај и улога граматике је вишезначна. Познавање граматике је подједнако битно у свим језичким вјештинама као што су писање, читање, слушање и говор, јер ученик не може написати, прочитати, слушати или исказати оно што не зна или не разумије. ${ }^{2}$

Само изучавање граматике, као што смо претходно поменули, се мијењало у зависности од доминатне теорије или метода. ${ }^{3}$ Када се вратимо пар деценија уназад, наилазимо, пак, на једно класично изучавање страног језика. У вези са тим, осврнућемо се на један добро познат метод, када је ријеч о усвајању станог језика, граматичко-преводилачки метод (eng. Grammar Translation Method). Граматичкопреводилачки метод се имплементирао у процес учења од 1840. до 1940., а и данас је нашао своје упориште у настави. ${ }^{4}$ Овај метод је граматичке вјежбе као и превођење писаног материјала користио као главни и једини начин усвајања страног језика. Они који су учили језик ослањајући се на овај метод нису користили процес повезивања и схваћања, него су сав језички материјал, као што су вокабулар и граматичка правила, учили напамет. Послије периода граматичко-преводилачког метода и доминантности граматике услиједила је реакција која је граматику потпуно избацила из процеса учења страних језика. Седамдесетих година, двадесетог вијека, долази период када је граматика поново интегрисана у цјелокупан процес учења страног језика. ${ }^{5}$ д данашњици не постоји метод који је најефикаснији за све ученике. Савјетује се да наставник испитује и имплементира разне методе у наставни процес, како би увидио који од метода најбоље помаже при процесу усвајања граматике. ${ }^{6}$

Овај рад за предмет узима контекст као начин/метод изучавања граматике, испитује присутност задатака који садрже контекст у настави и ставове ученика о самом процесу учења граматике. Главни циљ је да се објасне предности које контекст носи са собом при процесу усвајања страног језика и прикаже гдје Европски оквир за живе језике позиционира граматику. Сматра се да је традиционални начин изучавање граматике, попут учења граматичких правила и терминологије, не доприноси да вјештина писања напредује или било која друга језичка вјештина.

1 Stokić 2012

2 Takahashi 2005

3 Parupalli 2019

4 Lovrić 2019

5 Stokić 2012

6 Parupalli 2019

7 Seliger 1979 
Стога, полазимо од хипотезе да, ако граматику не поставимо у аутентичан контекст, као што је то на примјер у облику текстова или видео материјала, ученици ће, на већим нивоима познавања језика, теже моћи да овладају продуктивним вјештинама као што су писање и говор.

\section{МЈЕСТО ГРАМАТИКА У САВРЕМЕНИМ ОКВИРИМА НАСТАВЕ}

Мјесто граматике у настави страног језика се мијењало сходно моделима наставе и потребама тржишта рада. Како су посљедњих деценија на тржишту рада најприсутнији послови који захтијевају добре комуникативне вјештине, тако се настава страног језика окренула ка комуникативном методу изучавања страног језика. Комуникативни метод наставе страног језика у први план ставља интеракцију између ученика и наставника, сав језички материјал се усваја, искључиво, током процеса комуникације. Овај метод не ставља значај на граматику и толерише језичке грешке. ${ }^{8}$ Са циљем да се ученик оспособи тако да без страха или неразумијевања комуницира у различитим ситуацијама на страном језику. Иако је комуникативни метод заступљен, изучавање граматике није потиснуто из образовног система. Самим тим, јер је комуникативни метод уско повезан са комуникативним компетенцијама, а Канали и Свејнова у оквиру ових компетенција обухватају граматичку (eng. grammar competence) , социолингвистичку (eng. sociolinguistic competence), дискурсну (eng. discourse competence) и стратешку (eng. strategic competence) компетенцију (Слика 1). ${ }^{9}$ Тим што у оквиру комуникативне компетенције наилазимо на додатне компетенције - није могуће развијати комуникациону компетенцију, а да се у исто вријеме не развијају остале. Када дође до напретка и побољшања у једној компоненти, та копонента ступа у интеракцију са преостале три како би се постигао истовјетни напредак у укупној комуникативној компетенцији. ${ }^{10}$

Слика 1. Компоненте комуникативне компетенције ${ }^{11}$

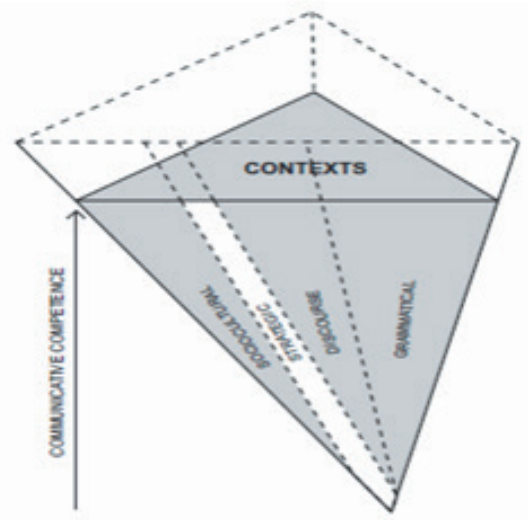


Поред заступљености комуникативног метода, граматика је и даље нашла своје упориште. Међутим, како граматичке компетенције према Канли и Свејновој представљају знање правила фонологије, вокабулара, синтаксе и семантике, граматика као језичка компонента ће захтијевати присутност у настави страног језика било да се ради о теоријском усвајању или примјени граматичке теорије у интерпретацији, изражавању и преношењу значења.

Када се говори о изучавању страних језика и самом систему изучавања треба поменути званични оквир који прописује стандардне смјернице за лакше сналажење у самом процесу изучавања језика и који описује језичке компетенције страних језика са циљем да се одређене ставке усагласе и лако препознају између земаља. Савјет Европе, у сарадњи са компетентним језичким институцијама, саставља заједнички европски референтни оквир за живе језике (eng. CEFR - Common European Framework of Reference for languages) ${ }^{12}$ који је по први пут објављен 2001. године.

Заједнички европски оквир пружа заједничку основу за разраду наставних планова и програма за изучавање језика, стандардних испита и уџбеника. Он на свеобухватан начин описује шта ученици треба да науче да би користили језик за комуникацију и која знања и вјештине треба да развију како би могли ефикасно да користе језик. Оквир такође покрива културни контекст у којем је језик постављен. Поред тога, дефинише нивое стручности који омогућавају мјерење напретка ученика у свакој фази учења и током цијелог живота. ${ }^{13}$ чињеница која чини овај документ важним за изучавањем страног језика јесте та што нуди детаљан опис и смјернице за сваку језичку вјештину за сваки језички ниво (почетни, средњи и напредни). Оно што је битно поменути јесте да заједнички европски оквир из 2001.године сматра граматику језичком компетенцијом. Самим тим, оквир ставља граматику у језичке вјештине и оцјењује је по принципу тачности изражавања. Аутори оквира нису представили описе који објашњавају граматичку компетенцију за сваки референтни ниво, него су представили на ограничен начин списак граматичких категорија и параметара. ${ }^{14}$ Овакво виђење граматике је поново потврђено у допунском документу (Companion Volume with New Descriptors, 2018). Представљајући граматику у виду компетенције је добра карактеристика из разлога јер је и чувени лингвиста, Ноам Чомски, тврдио да се компетенција односи на лингвистички систем тј. граматику. Његовом тврдњом долазимо до закључка да иако језички оквир за живе језике представља граматику ${ }^{15}$ у виду језичке компетенције, њено изучавања ће бити интегрисано у наставни процес.

У прилог томе, да је граматика данас заступљена указују нам и чињеница да бројни интернационални, званични, језички цертификати попут ТОЕФЛ (Test of English as a Foreign Language, TOEFL) и кембриџ цертификата у процес тестирања интегришу граматику. ${ }^{16}$

12 The Common European Framework of Reference for Languages (CEFR), према https://www.coe.int/en/web/common-european-framework-reference-languages/level-descriptions

13 Council of Europe 2001

14 Council of Europe 2001,114

15 Chomsky 1965

16 Bodrič 2016 
Оно што је посебно интересатно за ТОЕФЛ тестове је то да формално они тестирају четири језичке вјештине: читање, слушање, писање и говор; међутим, оно што се тестира у оквиру писања и говора је управо граматика у употреби. Свака компонента која сачињава један језик је подједнако важна, тиме је немогуће истиснути ни граматику, ни било коју другу компоненту из процеса учења језика.

\section{ГРАМАТИКА У КОНТЕКСТУ}

Граматика у средњим школама је често представљена на начин да је ученици виде попут нечега што је сама теорија. Разлог томе је што први контак са граматиком, још у основној школи, представљен путем дедуктивног метода. Дедуктивни метод се служи тезом од општег ка посебног. ${ }^{17}$ Теза указује на то да се, примјеном дедуктивног метода, прво креће од представљања граматичких правила ученицима, затим се поменута правила користе на практичним примјерима. Главни проблем који се јавља је чињеница да се овај метод наставља примјењивати и у каснијим годинама изучавња, када су ученици већ достигли средњи или напредни ниво енглеског језика. Ову тврдњу су потврдили и језички научници који кажу да је дедуктивни приступ мање погодан за ученике виших нивоа језика и за предстаљање граматичких структура које су по својој природи сложеније како по форми тако и по значењу. ${ }^{18}$ Један од разлога зашто је овај метод толико дуго држао монопол над другима јесте тај, што су уџбеници страног језика били скројени према том моделу. ${ }^{19}$ Одређени напредак се, данас, може видјети у образовном систему, захваљујући модерној технологији која се све више имплементира у наставни процес. Путем савремених достигнућа ученици имају прилику да буду изложени конструкцијама живог језика, а и садржај уџбеника се знатно измијенио. Тако данас уџбеници енглеског језика су усклађени по референтном оквиру и нивоима - тиме садржај уџбеника средњег и напредног нивоа посједује различите вјежбе које нису конструисане искључиво по дедуктивном методу. Поред дедуктивног метода, наилазимо на још један добро познати метод у литератури тј. индуктивни метод. Наиме, овај метод не представља ученицима граматичка правила, него помоћу језичких цјелина или вјежби наводи ученике да сами открију принцип или правило. ${ }^{20}$ Сматра се да је овај метод баш због своје когнитивне природе и тога што наводи ученике на рјешење прикладан за више нивое енглеског језика. Циљ овог метода лежи у томе да се језик учи посредством живог, језичког контекста тако да ученици могу научити не само правила већ и њихову употребу у свакодневном животу. ${ }^{21}$ Језички контекст ће бити управо тај који ће помоћи ученицима при изради прецизних граматичких реченица. Заправо, контекст је мисаона цјелина која окружује ријечи и реченице, при томе директно утиче на значење и структуру језичког исказа.

17 Widodo 2006

18 Goner, Phillips, \& Walters 1995

19 Fortune 1992

20 Nunan 2003

21 Mohammad 2017 
Међутим, када говоримо о контексту и његовој примјени, у већини случајева неће бити представљен путем дедуктивног метода из разлога јер дедуктивни метод објашњава одређена граматичка правила и захтијева њихову употребу у простим реченицама које не садрже шири контект. Стога је и сама теорија, која указује да употреба дедуктивног метода на вишим нивоима није адекватна, прихватљива. Од ученика на вишим нивоима, као што је случај са ученицима завршних година средње школе, се очекује да су усвојили довољно знања како би се могло приступити изучавању језика на вишим нивоима.Тиме се жели рећи, да је изучавање граматике ван контекста од велике користи на почетним нивоима, међутим, изучавање граматике унутар контекста је продуктивније за више нивое. Заједнички европски референтни оквир за живе језике (CEFR) је указао на то да ученици на средњем и напредном нивоу изучавања страног језика за исход могу разумјети главне идеје комплексног текста, могу саставити детаљан текст о различитом спектру тема и објаснити ставове о актуелном питањима и сл. Како би ученици били оспособљени да након завршетка средњошколског школовања буду у могућности да без проблема изврше горе наведене приједлоге онда се сам процес наставе мора усагласити са исходима учењима. По питању изучавања граматике то ће значити да се граматичке цјелине морају вјежбати посредством ширег контекста, како би ученици могли за крајњи исход бити спремни да прије свега разумију, а потом и самостално изразе комплексне мисаоне цјелине.

Да бисмо приказали важност контекста у граматици, кренућемо од тога како контекст утиче на вокабуларни систем енглеског језика и граматичку форму. На првом примјеру ћемо на један тривијалан начин приказати контекст - његов утицај на вокабуларни систем језика; као алат узећемо двије енглеске ријечи iron и hair које имају више значење, самим тим, контекст је једино оно што ће одредити природу значења ријечи.

\section{Примјер 1}

The gates are made of iron. It's metal / Капије су од гвожђа. То је метал.

We need a new iron. This one does not work. / Требамо нову пеглу. Ова не ради.

Mark's hair is dark and curly. / Маркова коса је тамна и коврџава.

I found a hair on my bed, it must be from your dog. / Нашао сам длаку на кревету, мора да је од твог пса.

Примјер 1 је указао на то да ће језички материјал, у овом случају ријеч, мијењати своје значење сходно контексту. Иако примјери не обилују ширим контекстом, контекст који се састоји у датим примјерима је довољан указатељ на значење ријечи. Из исказ We need a new iron. This one does not work закључујемо да ријеч iron носи значење пегле, међутим, када бисмо скратили контест и избацили исказ This one does not work изгубило би се јасно значење ријечи. Поред тога, што контекст у датим примјерима утиче на значење ријечи, он ће утицати и на граматичке јединице. У зависности од значења које ријечи iron и hair $^{22}$ носе са собом граматичка множина неће бити иста, самим тим ће доћи и до промјене у употреби чланова енглеског језика у датим реченицама.

22 За даље читање о бројивости именица iron и hair можете пронаћи на сљедећим линковима: https://dictionary.cambridge.org/dictionary/english/iron https://dictionary.cambridge.org/dictionary/english/hair 
Тиме долазимо да закључка да је контекст подједнако важан у свим језичким цјелинама. Лингвистичка дисциплина која се бави проучавањем контекста је прагматика. Прецизније речено, прагматика проучава начин на који контекст може утицати на разумијевање језичког исказа. ${ }^{23}$ Са друге стране, лингвистичка дисциплина која је генерално дефинисана као проучавање значења, јесте семантика. ${ }^{24}$

Узимајући у обзир чињеницу да контекст утиче на разумијевање језичког исказа, без сумње ће контекст утицати и на граматички облик као и граматичко значење. У наставку ће реченице, преузете из уџбеника Advanced Grammar in Use, ${ }^{25}$ покушати да прикажу како два слична исказа у зависности од контекста у коме се налазе имају различито граматичко значење и форму.

\section{Примјер 2}

A1. I didn't shave this morning.

A2. I haven't shaved this morning.

У примјерима A1 и А2 наилазимо на употребу два различита глаголска времена у истој реченици Past Simple и Present Perfect Simple. Реченице се налазе у изолованој средини тј. изван контекста. До разлике у глаголским временима наилазимо из разлога јер аутори ових реченица гледају догађаје из различитих перспектива тиме се жели рећи да аутори обје реченице имају различит контекст. Тако аутор A1 реченице ставља акценат на прошлу радњу, гдје указује на комплетираност или свршеност радње самим тим опредјељује се за употребу Past Simple. Са друге стране, аутор реченице A2 има другачији контекст, он не наглашава комплетираност радње, напротив, он наглашава да је радња и даље у процесу. Овакве издвојене реченице ван контекста не дају много информација о значењу поруке или исказа, такође се њихова тачност не може оспорити, јер су оба глаголска времена прихватљива у изолованој средини. Овим се жели показати да учење граматике у изолованој средини на вишим нивоима језика није прикладно - ученици треба поред грматичких правила да развијају способност сналажења у контексту, како би усвојена правила могли адекватно примијетити у различитим сферама. Како су употреба и разумијевање језика фактор наше способности да сагледавамо и обрађујемо дијелове дискурса тј. контекста, поред тога и да формулишемо приказе значења не само из једне реченице, већ и из референци у претходним и сљедећим реченицама. ${ }^{26}$ Стога се овај рад залаже за изучавање граматике унутар контекста, тиме бисмо на поменуте реченице креирали шири контекст како бисмо нашли оправданост за употребу оба времена. На примјер, на реченицу А1 бисмо додали контекст који ће указати на употребу Past Simple и уједно спријечити употребу Present Perfect Simple: The day passed quickly. There was a lot of work today. I guess I will have a lot of paperwork to finish tomorrow. Now, I'm going to shave because I didn't shave this morning.

23 Lepore \& Smith 2008

24 Gavranović 2020

25 Hewings 2005

26 Brown 1980 
У овако формираном контексту, који не изискује тежак ниво разумијевања приказали смо како би требало да се приступи изучавању граматике и примјени њених правила. Језик је контекстуално осјетљив - то значи да је, у одсуству контекста, веома тешко повратити предвиђено значење једне ријечи или фразе. ${ }^{27}$

\section{ТИПОВИ ГРАМАТИЧКИХ ЗАДАТАКА}

Нуан у свом раду тврди да је граматика често представљена изван контекста у уџбеницима. ${ }^{28}$ Ученицима се у наставном процесу дају вјежбе које садрже реченице у изолованој средини и које захтијевају неку врсту граматичке трансформације и понављања. Када кажемо понављање, првенствено мислимо на оне вјежбе које захтијевају од ученика да у свакој реченици ураде исту мисао - чиме ученици стичу знање манипулације и пресликавање. Овакав тип вјежби је више него прикладан на нижим нивоима изучавања страног језика, међутим, када је ријеч о вишим нивоима оне не дају много простора за напредовање. У свом научном раду Радмила Бодрич указује на чињеницу да поједини испитаници постижу боље резултате у задацима вишеструког избора, него у интервјуу, или, пак на писменом саставу него у тзв. клоз-тесту. ${ }^{29}$ Таква чињеница, заправо, није изненађујућа из разлога јер типови задатака, као што је писање састава или разговор на задату тему изискују познавање граматичких правила унутар контекста. У оваквим типовима задатака се од ученика очекује да користе граматику у контексту, стога, да би студенти били ефикасни у оваквим задацима морају прво да се сусретну са ширим контекстом који ће садржати разне језичке материјале попут граматике и вокабулара. Постоји трврдња да се треба прећи на контекстуализовану наставу која користи аутентичне и дуже текстове за учење граматичких правила, јер није добро да се само настава сведе на подучавања граматике кроз вјежбе из радних листова. ${ }^{30}$ Са таквим приступом постигли бисмо уједно да ученици развију и језик у контекстуалној употреби. Пошто се рад бави изучавањем граматике енглеског језика завршних година средњих школа треба имати на уму да ће одређени број ученика након завршетка средњошколског образовања наставити своје студије усмјерене ка језицима, самим тим ће полагање пријемног исписта из енглеског језика бити нешто што је за очекивати. Фокусираћемо се на типове задатака које ученици, будући студети, могу очекивати на пријемном испиту из енглесдког језика на Филолошком факултету у Београду. Типови задатака које Филолошки факултет саставља садрже контекстуалну природу, самим тим се од ученика средњих школа очекује да су након четворогодишњих студија спремни да исте ријеше. У прилогу се налази један од задатака са пријеменог испита из 2020. године (Слика 2) који захтијева познавање граматичких правила, вокабулара као и контекста.

27 Thornbury 1999

28 Nunan 1998

29 Bodrič 2016

30 Tommaso 2005 


\section{Задатак 1}

Слика 2. Примјер задатка са пријемног испита (Филолошки факултет, Београд) ${ }^{31}$

\section{I - Read the whole text carefully, choose the correct answer, and mark it on your answer sheet:}

Ferguson had thought he was smitten with Linda, but after (1) her throughout the fall and winter, determined to win her affections, he had (2) to the conclusion that not only (3) but that he didn't love her. After weeks of effort, Ferguson had finally persuaded her to say yes (4) on one of his trips to Manhattan. The plan was simple: lunch at the restaurant, and then a couple of hours in the dark watching a film, and if, during the course of the film, Ferguson (5) to hold Linda's hand, so much the better. It turned out to be a gloomy day, colder than they (6) for that time of the year, but nothing about early spring was ever normal, Ferguson said, as they (7) forming on the sidewalk, and he was sorry about the rain, he continued, but it wasn't really his fault, since he had written a letter to Zeus last week (8) sunny weather, and how could he have known they were in the middle of a monthlong postal strike (9) ? Linda laughed at the silly remark, which seemed to suggest they were (10) to a promising start, but then they boarded the train. The dirt and noise of big-city life filled her with an instinctive revulsion, as if she (11) a bad smell and she suddenly felt sick to her stomach. She couldn't help it, Ferguson repeated to himself, and therefore she couldn't be blamed. While (12) 57 th Street, he wondered (13) once they entered the theatre and settled in to watch the film.

(Based on: 432I, Paul Auster)

1. A. pieking

B. persecuting:

C. prosecuting

D. pursuing

2. A. arrived

B. drawn

C. come

D. reached

3. A. she didn't love him

B. did she not love him

$C$, she hadn't loved him

$D$ had she not loved him

4. A. to accompany him

B. to accompanying him

C. to make him company

D. to making him company

5. A. was ablo

B. is able

C. would be able

D. will be able
6.

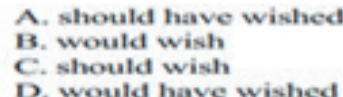

7.

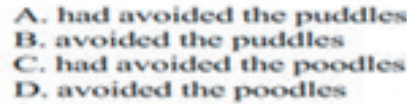

8. A. asking for a

B. asking for

C. requesting for a

D. requesting for

9. A. at Mount Olympus

B. at the Mount Olympus

C. on Mount Olympus

D, on the Mount Olympus

10. A. about

B. down

13. dow

D. on
11. A. were breathing in

B. has breathed in

C. would breathe in

D is breathing in

12. A. muiding her along the

B. having guided her along the

C. guiding her along

D. having guided her along

13. A. would her spirits improve B. if her spirits would improve C. would her spirits raise $D$, if her spirits would raise

Из првог задатка можемо закључити да ученици који буду жељели да полажу пријемни испит из енглеског језика мораће да буду спремни да сва језичка правила, значења имплементирају у обимнији контекст, у овом случају одломак из књижевног дјела. Задатак обухвата бројне граматичке цјелине које захтијевају адекватну примјену унутар контекста. Процјењује се да само познавање граматичких правила није довољно при рјешавању овог типа задатака, јер велики број граматичких цјелина које када уметнемо у смислени контекст мијењају своју првобитну употребу и усклађују се датим контекстом. Како би ученици били спремни на овакав вид задатака, рад предлаже да се у наставни процес имплементира процес наставе 
тако да наставници, у случајевима, када уџбеници којима се служе не обилују живим језичким контекстом да уведу додатне материјале које садрже вјежбе са контекстом, попут задатка један. У том случају предлажемо уџбеник „Граматика у Контексту“ (eng. Grammar in Context by Hugh Gethin). Књига је намијењена вишим новима изучавања енглеског језика, али се може прилагодити и на средњи ниво. Типови задатака које књига садржи (Слика 3) представљају живи језички материјал тј. реалан контекст који студенти могу сусрести у свакодневном животу говорника енглеског језика.

\section{Задатак 2}

Слика 3. Примјер задатка из граматичке књиге ${ }^{32}$

For each verb in brackets, choose one of the following tenses: the PRESENT, PRESENT PERFECT, PAST or PAST PERFECT, in either the SIMPLE or PROGRESSIVE form. If, as well as the verb, there is another word (an adverb) inside the brackets, its position in relation to the correct tense is shown either in the Examples or in the Explanation.

Brenda Pearl ( 1 join) our firm ten years ago. She ( 2 work) for the previous five years with an advertising company and ( 3 acquire) much useful experience. For the first eight years with us she ( 4 work) in the Sales Department, and ( 5 work) there when I ( 6 become) Managing Director. Since then she ( 7 work) as my personal assistant, and ( 8 prove) herself to be outstandingly capable on many occasions. She ( 9 work) on the top floor, in an office next to mine, but at the moment ( 10 work) in London on a special assignment.

When the North and South finally (11 lay) down their arms in 1865 at the end of the American Civil War they (12 fight) for over four years and the South, which (13 win) several battles but (14 lose) the war, (15 be) economically exhausted. It (16 be) a tragedy that Abraham Lincoln, who (17 lead) the North to victory and (18 be) now ready to be generous to the South, (19 not|survive) to make the peace. Five days after General Lee (20 surrender) at Appomattox, Lincoln ( 21 be) assassinated.

У задатку два можемо видјети типове задатака које би требало потенцирати у наставни процес изучавања граматике у завршним разредима средње школе. На овај начин ученици ће створити реалну слику како се сва граматичка правила примјењују у реалном језичком оквиру. Не само, да ће примјеном ових задатака бити способни да примјене правила у оваквим типовима задатака, него ће бити оспособљени да у процесу комуникације примијене шири контекст који ће засигурно садржати сва она претходно научена правила. Било да ученици полажу пријемни испит или полажу интернационалне тестове како би стекли званичне цертификате, примјена контекста у процесу учења језика ће учинити да ученици буду спремни да користе језик у било ком контексту. 


\section{МЕТОДОЛОГИЈА ИСТРАЖИВАҢА}

Истраживање се фокусира на корпусу који се састоји од тридесет упитника ученика треће и четврте године гимназије (општи смјер) „ Милутин Миланковић, Милићи" из Босне и Херцеговине. Процјењује се да ученици изучавају енглески језик, у просјеку, око десет година. Судећи по уџбенику по којем ученици прате наставу можемо говорити о средњем нивоу (Б2) и напредном нивоу ( Ц1). Узимајући у обзир да се настава када је истраживање спроведено, у првом полугодишту наставне године 2020/21, одвијала под ванредним условима због пандемије коронавируса - тиме нисмо могли тестирати на коме се ниову по референтном оквиру ученици налазе. Међутим, то није спријечило истраживање да се спроведе. Циљ истраживања је да се испитају ставови ученика о изучавању граматике и примјени контекста у наставном процесу. Поред тога, истраживање је садржало један задатак од пет реченица који је за циљ имао да провјери колико ученици размишљају о контексту при примјени граматичких правила. Првобитно, циљ је био да се ученици изложе задатку један (Слика 2) са пријемног испита али како су часови били скраћени то није било могуће. Задатак који су ученици радили је садржао примјену основних граматичких правила, међутим, задатак је осмишљен тако да, иако се ради о основним граматичким цјелинама, ученици треба да размишљају о различитим контекстима, те у складу са њима искористе и различита граматичка правила.

Метода примијењена у овом истраживању је квантитативне природе. Упитник и задатак су анализирани на начин да могу да прикажу број ученика који сматрају да је контекст од круциалне важности при изучавању граматике, такође и да укаже колико студенти при изради задатка владају контекстом и колико су спремни да раде на напредном нивоу енглеског језика.

\section{АНАЛИЗА ПОДАТАКА И ДИСКУСИЈА}

Започевши ово истраживање, са циљем да укажемо на важност контеста приликом изучавање граматике на вишим нивоима енглеског језика у средњим школама, а ослањајући се на ставове ученика и њихова постигнућа на задатом задатку представљамо вам резултате испитаних ставова и анализу задатка у табели 1 и 2. 
табела 1. Резултати испитаних ставова ученика о примјени контекста

\begin{tabular}{|c|c|c|c|c|c|}
\hline ПИТАЊЕ & 1 & 2 & 3 & 4 & 5 \\
\hline $\begin{array}{l}\text { 1. Да ли сматрате да је изучавање граматике } \\
\text { енглеског језика подједнако битно као и } \\
\text { изучавање вокабулара? }\end{array}$ & $10 \%$ & $5,66 \%$ & $20 \%$ & $26,66 \%$ & $36,66 \%$ \\
\hline $\begin{array}{l}\text { 2. Да ли су ваши часови енглеског језика } \\
\text { фокусирани на граматиче цјелине? }\end{array}$ & $6,66 \%$ & $13,33 \%$ & $33,33 \%$ & $33,33 \%$ & $13,33 \%$ \\
\hline $\begin{array}{l}\text { 3. Током обраде текстова из уџбеника да ли заједно } \\
\text { са предметним наставником коментаришете } \\
\text { употребу одређених граматичких цјелина? }\end{array}$ & $13,33 \%$ & $0 \%$ & $26,66 \%$ & $16,66 \%$ & $43,33 \%$ \\
\hline $\begin{array}{l}\text { 4. Да ли сматрате да ће, некада, контекст одредити } \\
\text { значење ријечи? }\end{array}$ & $3,33 \%$ & $3,33 \%$ & $23,33 \%$ & $23,33 \%$ & 46,66 \\
\hline $\begin{array}{l}\text { 5. Граматиче цјелине се лакше усвајају у } \\
\text { изолованој средини? }\end{array}$ & $10 \%$ & $33,33 \%$ & $23,33 \%$ & $6,66 \%$ & $26,66 \%$ \\
\hline $\begin{array}{l}\text { 6. Граматичке цјелине се лакше усвајају када су } \\
\text { уметнуте у контекст? }\end{array}$ & $3,33 \%$ & $0 \%$ & $26,66 \%$ & $20 \%$ & $50 \%$ \\
\hline $\begin{array}{l}\text { 7. Приликом обраде граматичких лекција- да } \\
\text { ли се скреће пажња на контекст? }\end{array}$ & $0 \%$ & $0 \%$ & $30 \%$ & $43,33 \%$ & $26,66 \%$ \\
\hline
\end{tabular}

Табела 1 представља листу истраживачких питања на која су испитаници дали одговоре (1-7) и бројеви у колонама од 1 до 5 означавају колико је ученика заокружило дату опцију. Наведени одговори су означени од 1 до 5, при чему 1 означава „упоште се не слажем“, 2 „не слажем се“, 3 „не знам“, 4 „слажем се“ и 5 "потпуно се слажем“.

Анализа ставова је показала да ученици (63,32\%) сматрају да је подједнако битно изучавање граматике, као и вокабулара у енглеском језику, што је показало чињеницу да су ученици свјесни важности граматике у процесу изучавања енглеског језика. Судећи по одговорима који су ученици дали на питање: „Да ли су часови фокусирани на граматичке јединице?" , долазимо до одговора да се подједнако ради и на граматици и на другим језичким елементима, што је свакако добра пракса приликом изучавања страног језика. Истраживање је такође показало да приликом обраде текстова из уџбеника ученицима се скреће пажња на граматичке јединице које се налазе у оргиналном контексту. Око 60\% ученика је потврдило овај начин рада приликом обраде ширег контекста. Да су студенти свјесни важности контекста приликом изучавања језика показао нам је и резултат да око 70\% ученика сматра да ће контекст одредити значење ријечи, као и да се граматичка правила лакше усвајају када су уметнута унутар контекста.

Извршивши испитивање ставова ученика о важности граматике и начину изучавања - кренули смо да испитамо колико се на практичним примјерима води рачуна о примјени контекста у реченицама које дозвољавају више тачних одговора из разлога јер постоје различите интерпретације тј. контексти. 
Као што је већ поменуто, због спровођења истраживања у измијењеним околностима рада средњих школа, морали смо да смањимо број задатака - па смо тако свели рад на један важан задатак. Иако је у питању само један задатак, он је успио да пружи одговоре на задатим питањима у самом раду. Тиме, у табели 2 представљамо пет реченица које су изоловане из контекста, при томе, од ученика се очекује да заокруже све тачне граматичке конструкције које могу стојати у одређеном контексту. Оно што треба нагласити јесте, да прије израде реченица ученицима на самом задатку је било наглашено да заокруже све могуће одговоре и да обрате пажњу на контекст у коме би се одређена цјелина могла наћи. У реченицама фокус је био на употреби простих времена попут простог садашњег, прошлог и будућег времена. Поред тога, једна од кључних граматичких јединица је била употреба чланова (eng. Articles) као и употреба једне ријечи са двојаким значењем (eng. statistics) у контексту и њено слагање са глаголском формом.

табела 2. Резултати практичне примјене граматике у зависности од контекста

\begin{tabular}{lll}
\hline РеченицА & $\begin{array}{l}\text { Потпуно тачне } \\
\text { реченице }\end{array}$ & $\begin{array}{l}\text { Нетачне } \\
\text { реченице }\end{array}$ \\
\hline $\begin{array}{l}\text { 1. Statistics........... interesting, however, they are out of date. } \\
\text { I are II is III aren't }\end{array}$ & $\begin{array}{l}9 \text { ученика } \\
30 \%\end{array}$ & $\begin{array}{l}21 \text { ученик } \\
70 \%\end{array}$ \\
\hline $\begin{array}{l}\text { 2. Statistics........... an interesting subject. } \\
\text { I are II is III isn't }\end{array}$ & $\begin{array}{l}3 \text { ученика } \\
10 \%\end{array}$ & $\begin{array}{l}27 \text { ученика } \\
90 \%\end{array}$ \\
\hline $\begin{array}{l}\text { 3. I.......... in school. } \\
\text { I was II am III will be }\end{array}$ & $\begin{array}{l}4 \text { ученика } \\
13,33 \%\end{array}$ & $\begin{array}{l}26 \text { ученика } \\
86,66 \%\end{array}$ \\
\hline $\begin{array}{l}\text { 4. She would like to watch........... film. } \\
\text { I a II the III - }\end{array}$ & $\begin{array}{l}6 \text { ученика } \\
20 \%\end{array}$ & $\begin{array}{l}24 \text { ученика } \\
80 \%\end{array}$ \\
\hline $\begin{array}{l}\text { 5. I can't believe we'll finally see what happened - wait for } \\
\text { my sister - She would like to watch........... film. }\end{array}$ & 18 ученика & 12 ученика \\
Ia II the III & $60 \%$ & $40 \%$ \\
\hline
\end{tabular}

Када је ријеч о колони која чини потпуно тачне реченице, треба напоменути да се у тој колони налазе само тачни одговори, у овом случају то ће значити да се под тачним одговорима сматрају само они одговори на које су ученици у цјелости тачно одговорили.

Анализирајући прву реченицу наилазимо на податак да је од 30 ученика - 9 ученика заокружило све могуће одговоре. Док у другој реченици која је слична претходној, 3 ученика је одговорила тачно. Анализом прве и друге реченице долазимо да закључка да ученицима није била јасна употреба ријечи statistics; у реченици један, ријеч је носила значење статистике, а у другој је означавала школски предмет „Статистика“ - стога се јавио проблем са слагањем субјекта и глагола, а поред тога у процесу анализе радова наишли смо и на неразумијевање контекста. 
Од посебног значаја за истраживање је била реченица три. У реченици три ученици су требали да заокруже све понуђене одговоре, међутим, само је 4 ученика препознало контексте и примјену граматичке цјелине унутар њих. Разлог зашто је реченица важна јесте чињеница да је реченица једноставна али у случајевима када немамо развијену свијест о контексту и свим могућим значењима долазимо до резултата да некада и наједноставније ствари без употребе осталих знања, у овом случају контекста, доводе до неуспјеха.

Употреба чланова је карактеристика реченица четири и пет. Од ученика се очекивало да познају основне особености чланова. У реченици четири одговори су: неодређен члан а и одређен члан the. Разлог за употребу ова два одговора јесте чињеница да ако је говорнику непознат објекат (филм) користиће неодређен члан, али ако је говорнику познат објекат онда ће се опредијелити за употребу одређеног члана. Како немамо шири контекст како бисмо увидјели да ли се ради о познатом или непознатом објекту, ученици су требали да препознају обје варијанте, међутим, 6 ученика од 30 је препознало употребу чланова и контекста. Иако је реченицу четири тачно урадило 6 ученика, реченицу пет са истим захтјевом је урадило тачно 18 ученика. У реченици пет наилазимо на шири контекст који је указао на употребу само одређеног члана, стога је већи број ученика одговорио тачно. Ова анализа нам је указала да ученици могу, када виде шири контекст, да препознају тачан одговор, док када је остављено ученицима сами да размотре контекст, резултати су лошији.

Након извршене анализе задатка долазимо до закључка, да ученици посједују одређено знање када су у питању испитане граматичке цјелине - оно што се показало је недовољно познавање контекста тј. недовољно размишљање о њему. Ученици који прате наставу усклађену са референтним оквирима, треба да оснаже усвојене граматичке цјелине и да са предметним наставником раде више на контекстуалном приступу изучавања граматике, како би ученици били спремни да размотре разне контексте.

\section{ЗАКљУЧАК}

Након детаљног увида у корпусни материјал, можемо да закључимо да, иако су ученици на вишим нивоима изучавања енглеског језика - требало би учврстити постојећа граматичка знања тако да се крене са увођењем задатака који садрже шири контекст. Истраживање је потврдило да ученици имају потешкоћа при изради задатака који захтијевају да се размишља о могућим контекстима у реченици. Насупрот томе, реченице које су садржале контекст који је условљавао само одређену граматичку цјелину, ученици су лакше препознавали одговор. Упитник који је испитивао ставове ученика је потврдио да ученици схватају значај граматике у процесу изучавања страног језика, као и да је контекст онај елемент који ће им помоћи да лакше савладају граматику и остале језичке цјелине.

Када год користимо језик, било да слушамо, читамо, говоримо или пишемо, то радимо у некој врсти контекста. Ситуације у којима се налазимо, мисли које желимо да изразимо и начин на који други реагују утичу на природу избора језика који 
доносимо. Ако ученицима не буде пружена могућност да истражују граматику у контексту, биће им тешко да у потпуности развију своје језичке вјештине на већем нивоу. Данас, граматичке инструкције су превазишле меморисање правила или дијалога и залажу се више у помагању ученицима да развију своју комуникативну компетенцију, потенцирајући задатке које омогућавају уочавање и подизање свијести о граматичким облицима и њиховој употреби; успон комуникативног метода у комбинацији са напретком технологије довели су до многих могућности за учење граматике у контексту и већим фокусом на значење. ${ }^{33}$ Пратећи одговарајући наставни метод и одговарајуће задатке на одређеном нивоу, ученици ће побољшати постигнућа у граматици, а такође и у учењу енглеског језика.

\section{БИБЛИОГРАФИЈА}

Bikowski Dawn (2018): Technology for Teaching Grammar. The TESOL Encyclopedia of English Language Teaching. New Jersey: Wiley Blackwell.

Bodrič Radmila (2016): Testiranje gramatike stranog jezika - savremena teorijska i praktična načela. Nasleđe XIII-34. Kragujevac: Filološko-umetnički fakultet,159-170

Bojović Milevica (2013): Značaj i razvoj komunikativne jezičke sposobnosti studenata u učenju engleskog jezika kao jezika struke. Beograd: Filološki fakultet.

Brown Henry Douglas (1980): Principles of Language Learning and Teaching. New Jersey: Prentice Hall.

Gavranović Valentina (2020): Towards a deeper understanding of meaning in language A courbook in English Semantics. Belgrade: The University of Singidunum.

Roger Gower, Diane Phillips \& Steve Walters (1995): Teaching Practice Handbook. Oxford: Macmillan,129-138.

Gethin Hugh (1983): Grammar in Contex. London: Collins ELT.

Vučković Mirjana \& Matić Jelena (2020): Zbirka testova sa prijemnih ispita iz engleskog jezika. Beograd: Filološki fakultet.

Canale Michael \& Swain Merrill (1980): Theoretical Bases of Communicative Approaches to Second Language Teaching and Testing. Applied Linguistics I-1.Oxford:Oxford University Press, 1-47

Council of Europe (2001): Common European Framework of Reference for Languages: Learning, Teaching, Assessment. Cambridge: Cambridge University Press.

Council of Europe (2018): Common European Framework of Reference for Languages: Learning, Teaching, Assessment - Companion Volume. Strasbourg: Council of Europe.

Lepore Ernie \& Smith Barry C. (2008): The Oxford Handbook of Philosophy of Language. Oxford: Oxford University Press.

Lovrić Natalija ( 2019): Metoda poučavanja pokretom u učenju stranoga jezika u ranoj i predškolskoj dobi. Rijeka: Učiteljski fakultet.

Lončarević Mira \& Subotić Ljiljana (2010): Uloga gramatike u nastavi stranog jezika. Norma XV-1. Sombor: Pedagoški fakultet, 61-79

Mohammad Taj \& Khan Soada Idris (2017): Assessing Teachers Perception on the efficiency (success) of Inductive Approach in an ESL/EFL Classroom: Grammar in Context. English Review: Journal of English Education V-2. Indonesia: Faculty of Teacher Training and Education.

33 Bikowski 2018 
Nunan David (2003): Practical English Language Teaching. New York: McGraw-Hill.

Nunan David (1998): Teaching Grammar in Context. ELT Journal LII-2. Oxford: Oxford University Press, 101-109

Parupalli Rao S. (2019): The Role of Grammar in English Language Teaching (ELT) Techniques. Research Journal of English (RJOE) IV-2. India: Oray's Publications, 239 - 249

Savignon Sandra J. (2002): Interpreting Communicative Language Teaching. New Haven: Yale University Press.

Seliger Herbert W. (1979): On the nature and function of language rules in language learning. TESOL Quarterly XIII-3. USA:TESOL International Association , 359-369

Stokić Tijana (2012): Metalingvistička Kompetencija u Nastavi Prevođenja na Univerzitetskom Nivou (Na materijalu engleskog i srpskog jezika). Beograd: Filološki fakultet.

Takahashi Mitsuko (2005): The Efficacy of Grammar Instruction in EFL classes in Japan. Kobe: Kobe University.

Tommaso Kathrynn (2005): Contextualized Grammar Instruction for College Transition Students.

Thornbury Scott (1999): How to Teach Grammar. England: Pearson Education Limited.

Fortune Alan (1992): Self-study grammar practice: Learners views and preferences. ELT Journal XLVI2.Oxford: Oxford University Press, 160-171

Hewings Martin (2005): Advanced grammar in use: A reference and practice book for advanced learners of English. Cambridge: Cambridge University Press.

Chomsky Noam (1965): Aspects of the theory of syntax. Journal of Linguistics III-1. Cambridge: Cambridge University Press.

Widodo Handoyo P. (2006): Approaches and procedures for teaching grammar. English Teaching: Practice and Critique V-1. Bingley: Emerald Publishing,122-141 


\section{THE IMPORTANCE OF CONTEXT FOR DEVELOPING GRAMMATICAL COMPETENCE OF SECONDARY SCHOOL STUDENTS}

\begin{abstract}
Summary:
None of us can deny the fact that we live in a world where we witness the progress and development of technology every day. The modern world has contributed in such a way that complex things become a resolved yarn. Apropos of that, the acquisition of English grammar at the high school level, even though it is extremely complex, with the help of achievements will facilitate the transfer of knowledge and the acquisition of grammar itself. Thus, today's professors are provided, via the Internet, with access to original language materials that ought to serve students to learn the language in the way that native speakers use it. The subject matter of this paper is the process of learning and acquiring grammar of the English language that we encounter within the curriculum of the final years of high school. The paper has been created with the aim of analyzing the place of grammar in the process of teaching English, ways and methods, as well as the types of tasks by which students acquire grammatical units. The emphasis is on context, its importance in the process of studying grammar at higher levels and the implementation of tasks that contain context. The analysis of tasks and attitudes has been conducted on the corpus consisting of the language exercise and the examined attitudes of the students in order to indicate the importance of context and opinions of the students about it.
\end{abstract}

Keywords:

the English language, grammar, methods, context, attitudes, types of tasks. 